\title{
Selective Catalytic Reduction of NOx with NH3 over Mn2O3 supported with different morphology of $\mathrm{CeO} 2$ Catalysts
}

\author{
Shyam Rao ${ }^{1}$, VIVEK PATEL ${ }^{1}$, and Sweta Sharma ${ }^{1}$ \\ ${ }^{1}$ Indian Institute of Technology Banaras Hindu University
}

October 18, 2021

\begin{abstract}
Three different morphologies of $\mathrm{CeO} 2$ supports (NP, NC, and NR) were prepared by hydrothermal method and further Mn2O3 is impregnated on $\mathrm{CeO} 2$ supports using wet-impregnation methods, and their activity for NO reduction using NH3-SCR technique is analysed. The prepared catalysts and supports are further characterized through scanning electron microscopy (SEM), Energydispersive X-ray spectroscopy (EDX), X-ray diffraction (XRD), X-ray Photoelectron Spectroscopy (XPS), and transmission electron microscopy (TEM), and Brunauer-Emmett-Teller (BET). The catalytic performance of Mn2O3/CeO2-NP has shown the highest conversion $(76.06 \%)$ compared to the other two catalysts in the temperature range of $50-450^{\circ} \mathrm{C}$.
\end{abstract}

Selective Catalytic Reduction of $\mathrm{NOx}$ with $\mathrm{NH}_{3}$ over $\mathrm{Mn}_{2} \mathrm{O}_{3}$ supported with different morphology of $\mathrm{CeO}_{2}$ Catalysts

S. S. Rao, V.K. Patel, Sweta*

Department of chemical engineering, Indian Institute of Technology (Banaras Hindu University) Varanasi, 221005, India

*shweta.che@itbhu.ac.in

\begin{abstract}
Three different morphologies of $\mathrm{CeO}_{2}$ supports (NP, NC, and NR) were prepared by hydrothermal method and further $\mathrm{Mn}_{2} \mathrm{O}_{3}$ is impregnated on $\mathrm{CeO}_{2}$ supports using wet-impregnation methods, and their activity for $\mathrm{NO}$ reduction using $\mathrm{NH}_{3}$-SCR technique is analysed. The prepared catalysts and supports are further characterized through scanning electron microscopy (SEM), Energy-dispersive X-ray spectroscopy (EDX), X-ray diffraction (XRD), X-ray Photoelectron Spectroscopy (XPS), and transmission electron microscopy (TEM), and Brunauer-Emmett-Teller (BET). The catalytic performance of $\mathrm{Mn}_{2} \mathrm{O}_{3} / \mathrm{CeO}_{2}-\mathrm{NP}$ has shown the highest conversion $(76.06 \%)$ compared to the other two catalysts in the temperature range of $50-450^{\circ} \mathrm{C}$.
\end{abstract}

\section{KEYWORDS}

$\mathrm{Mn}_{2} \mathrm{O}_{3}, \mathrm{CeO}_{2}$ morphology, $\mathrm{NH}_{3}-\mathrm{SCR}$.

\section{INTRODUCTION}

The exponential growth of population and industrialization led to the emission of various pollutants in the environment, causes adverse effects on our environment and subsequently leading to climate change. Nitrogen oxides $\left(\mathrm{NO}_{\mathrm{x}}\right)$, one of the major air pollutants, emitted from mobile and stationary sources cause genuine environmental issues, such as photochemical smog, acid rain, ozone depletion, and greenhouse effects.

${ }_{1,2}$ At present, various strict environmental legislations are being implemented worldwide to reduce the 
concentration of $\mathrm{NO}_{\mathrm{x}}$ before releasing it into the environment. ${ }^{1,3}$ There are many techniques, such as nonselective catalytic reduction $(\mathrm{NSCR})^{3}$, selective catalytic reduction $(\mathrm{SCR})^{4,5}$, photocatalytic ${ }^{6,7}$ etc., out of which selective catalytic reduction with ammonia $\left(\mathrm{NH}_{3}-\mathrm{SCR}\right)$ is one of the most efficient methods for $\mathrm{NO}_{\mathrm{x}}$ reduction. It is more useful for exhaust emissions from stationary sources. In this process, $\mathrm{NO}_{\mathrm{x}}$ emissions are converted into water vapors and nitrogen gas molecules as depicted in equations (1) and (2) ${ }^{8,9}$.

$4 \mathrm{NO}+4 \mathrm{NH}_{3}+\mathrm{O}_{2} 4 \mathrm{~N}_{2}+6 \mathrm{H}_{2} \mathrm{O}(1) 2 \mathrm{NO}_{2}+4 \mathrm{NH}_{3}+\mathrm{O}_{2} 3 \mathrm{~N}_{2}+6 \mathrm{H}_{2} \mathrm{O}(2)$

$\mathrm{V}_{2} \mathrm{O}_{5}-\mathrm{WO}_{3} / \mathrm{TiO}_{2}$ based catalysts are widely used in $\mathrm{NH}_{3}$-SCR due to their cost effectiveness, best de-nitration efficiency, good sulfur resistance within a temperature range of $300-400^{\circ} \mathrm{C}$. Though, there are certain disadvantages of vanadium-based catalysts such as its narrow temperature window, the high toxicity of $\mathrm{V}_{2} \mathrm{O}_{5}$, high oxidation activity towards $\mathrm{SO}_{2}$ converted into $\mathrm{SO}_{3}$, and $\mathrm{N}_{2} \mathrm{O}$ production at higher temperatures ${ }^{10,11,12}$. The gases exhausted from stationary sources, for example, steel, cement, and glass plants are in a temperature range of 100-200degC ${ }^{13,14}$. Therefore, extra energy is needed to heat the exhaust gasses to give good performance by $\mathrm{NH}_{3}$-SCR catalysts ${ }^{15,16}$. Therefore, there is a need to develop a suitable catalyst whose performance should be high at the low-temperature range of $100-300^{\circ} \mathrm{C}$.

Mn-based catalysts have been thoroughly explored for the reduction of $\mathrm{NO}_{\mathrm{x}}$ by $\mathrm{NH}_{3}$-SCR in the last few years due to their excellent low-temperature catalytic activity ${ }^{17,18,19}$. It has been observed that $\mathrm{MnO}_{\mathrm{x}}-\mathrm{CeO}_{2}$ catalysts, among the many bimetallic oxides, have a lot of potential owing to the high oxygen storage capacity of $\mathrm{CeO}_{2}{ }^{16,23}$. In addition, some other properties such as morphology and microstructure of catalysts also influence the catalytic activity and selectivity by changing active site pore structure and dispersion ${ }^{8,9,12}$. Chao et al. found that $\mathrm{MnO}_{\mathrm{x}}-\mathrm{CeO}_{2}-\mathrm{Al}_{2} \mathrm{O}_{3}$ catalysts showed high $\mathrm{NO}_{\mathrm{x}}$ conversion and strong redox ability at low temperatures ${ }^{25}$. $\mathrm{Li}$ et al. synthesized Mesoporous $\mathrm{MnO}_{\mathrm{x}}-\mathrm{CeO}_{2}$ composites ${ }^{26}$, which gave better performance for $\mathrm{NO}_{\mathrm{x}}$ conversion as well as exhibited significant resistance to $\mathrm{SO}_{2}$, and $\mathrm{H}_{2} \mathrm{O}$. Yiran et al. synthesized $\mathrm{MnCoO}_{\mathrm{x}}$ catalysts with hollow nanotube structure ${ }^{27}$, which exhibited high $\mathrm{NO}_{\mathrm{x}}$ conversion at $150^{\circ} \mathrm{C}$ even under the co-existence of inhibitors like $\mathrm{H}_{2} \mathrm{O}, \mathrm{SO}_{2}$, and alkali metals. The template-based methods are also found to be useful for $\mathrm{NO}_{\mathrm{x}}$ reduction, Liu et al. compared the performances of MnCe oxide prepared with surfactant-template (ST) and co-precipitation (CP) methods. The activity results showed that the catalyst prepared by ST methods exhibited much better $\mathrm{NO}_{\mathrm{x}}$ reduction and high $\mathrm{SO}_{2}$ and $\mathrm{H}_{2} \mathrm{O}$ resistance in comparison to catalyst prepared by $\mathrm{CP}$ method at the temperature range of $100-200^{\circ} \mathrm{C}^{18}$.

From above discussion it can be conclude that efforts in the area of improving morphology of the overall structures or supports in order to gain promising support-metal interaction is very much of interest. Working in this direction, a series of supported $\mathrm{Mn}_{2} \mathrm{O}_{3} / \mathrm{CeO}_{2}$ with different support morphologies, were successfully synthesized to study the support morphology influence on metal-support interaction.

\section{EXPERIMENTAL}

\section{Materials and methods}

All chemicals and gases were procured commercially and used without any additional processing. Cerium (III) nitrate hexahydrate $\left(\mathrm{Ce}\left(\mathrm{NO}_{3}\right)_{3} * 6 \mathrm{H}_{2} \mathrm{O}, 99.0 \%\right)$, Sodium hydroxide ( $\left.\mathrm{NaOH}, 98 \%\right)$, ethanol $(99 \%)$, and Manganese nitrate tetra-hydrate $\left(\mathrm{MnN}_{2} \mathrm{O}_{6} .4 \mathrm{H}_{2} \mathrm{O}\right.$, [?] 97\%) were purchased from SRL Pvt. Ltd., Chemikabiochemika-reagents, SD fine-chemical limited and Sigma-Aldrich Factory, respectively. $\mathrm{NH}_{3}(1000 \mathrm{ppm}$, Ar balanced), $\mathrm{NO}$ (1000 ppm, Ar balanced), $\mathrm{O}_{2}$ (6 vol \%, Ar balanced), $\mathrm{N}_{2}$ (99.999\%) were used in the activity valuation experiments for NOx conversion.

\section{Catalyst preparation}

Three different morphologies (Nanorod, Nanocube, and Nanoparticle) of ceria supports were prepared using hydrothermal process by varying the synthesis parameters such as $\mathrm{C}_{\mathrm{NaOH}}$ (mole), temperature (0C) and reaction time (hr) as shown in Table1. An aqueous solution of $\mathrm{Ce}\left(\mathrm{NO}_{3}\right)_{3} \cdot 6 \mathrm{H}_{2} \mathrm{O}(5 \mathrm{mmol})$ is mixed with a precipitant $\mathrm{NaOH}$ solution of varying concentration at room temperature for one hr under continuous stirring to obtain uniform mixture. After this, the prepared mixtures were transferred into a Teflon-lined 
autoclave $(100 \mathrm{ml})$ at varied reaction temperatures and reaction times, anticipating different morphological structures. The formed hydrothermal precipitate in the autoclave was cooled down to room temperature and then washed several times with ethanol and de-ionized to eliminate any possible ionic impurities. After that, the thoroughly washed precipitates were dried at $65^{\circ} \mathrm{C}$ overnight and air calcined at $500^{\circ} \mathrm{C}$ for $4 \mathrm{hr}$, resulting in formation of different $\mathrm{CeO}_{2}$ supports denoted as $\mathrm{CeO}_{2}-\mathrm{NR}, \mathrm{CeO}_{2}-\mathrm{NC}$, and $\mathrm{CeO}_{2}-\mathrm{NP}$ in the manuscript. Further, Manganese (III) oxide was employed as a metal oxide precursor and was impregnated on the support using the wet-impregnation process. An aqueous solution of prepared $\mathrm{CeO}_{2}$ supports $\left(\mathrm{CeO}_{2}-\mathrm{NR}, \mathrm{CeO}_{2}-\mathrm{NC}\right.$, and $\left.\mathrm{CeO}_{2}-\mathrm{NP}\right)$ were mixed with a particular amount of commercial $\mathrm{Mn}_{2} \mathrm{O}_{3}(10 \mathrm{wt} \%)$.

TABLE 1 . Different condition for $\mathrm{CeO}_{2}$ supports synthesis

\begin{tabular}{llll}
\hline $\mathbf{C}_{\text {NaOH }}($ mole) & Temperature $\left({ }^{\mathbf{o}} \mathbf{C}\right)$ & Time $($ hr $)$ & Shape \\
\hline 7 & 100 & 12 & $\mathrm{CeO}_{2}-\mathrm{NR}$ \\
15 & 180 & 24 & $\mathrm{CeO}_{2}-\mathrm{NC}$ \\
10 & 130 & 24 & $\mathrm{CeO}_{2} \mathrm{NP}$ \\
\hline
\end{tabular}

The obtained mixtures were agitated until the metal oxide and support were evenly mixed, and then the solutions were dried overnight at $100^{\circ} \mathrm{C}$ and air calcined for $4 \mathrm{hr}$ at $350^{\circ} \mathrm{C}$. The resultant impregnated catalysts are denoted as $\mathrm{Mn}_{2} \mathrm{O}_{3} / \mathrm{CeO}_{2}-\mathrm{NR}, \mathrm{Mn}_{2} \mathrm{O}_{3} / \mathrm{CeO}_{2}-\mathrm{NC}$, and $\mathrm{Mn}_{2} \mathrm{O}_{3} / \mathrm{CeO}_{2}-\mathrm{NP}$ in this manuscript for reference.

\subsection{Characterization}

The X-Ray Diffraction system (Rigaku Miniflex 600) was used to obtain XRD patterns of the catalysts (RIGAKU Corporation). A nickel filtered $\mathrm{Cu}$ Ka radiation source was used in an X-ray diffraction apparatus. The intensity data were taken at a scanning rate of $5^{\circ} / \mathrm{min}$ in the range of $10^{\circ}[?] 2 \vartheta[?] 80^{\circ}$. The crystallite sizes of the catalysts were calculated using the Scherrer equation, and the crystalline phases of the materials were established by comparing the XRD patterns to reference data from the International Center for Diffraction Data (ICDD) files.

The specific surface area and pore volume of the prepared catalysts were determined using $\mathrm{N}_{2}$ physisorption at $77^{\circ} \mathrm{K}$ liquid nitrogen temperature (Micromeritics ASAP 2020, USA). The samples were degassed at $300^{\circ} \mathrm{C}$ for 5 hours to $\mathrm{N}_{2}$ physisorption.

The atomic surface of catalysts was analyzed using X-ray photoelectron spectroscopy (XPS), which was evaluated using Al Ka radiation by an X-ray photoelectron spectroscopy (AMICUS, Kratos Analytical) $(1486.6 \mathrm{eV})$. The binding energies of $\mathrm{O} 1 \mathrm{~s}, \mathrm{Mn} 2 \mathrm{p}$, and Ce $3 \mathrm{~d}$ were calibrated using the $\mathrm{C} 1 \mathrm{~s}$ peak's binding energy $(284.8 \mathrm{eV})$ as a reference and origin software was used to de-convolute the spectra.

To determine the morphology and particles size distribution of the supports and catalysts transmission electron microscopic (TEM) images were taken with a JEOL JEM-2100 system operated at $200 \mathrm{KV}$. The SEM images of the catalysts were obtained after scanning by the surface SEM: EVO 18-20-45 system electronmicroscope. In a pulse chemi sorb $2705, \mathrm{H}_{2}-\mathrm{TPR}$ was employed to analyze the reducibility of the catalysts (Micromeritics, USA). The catalysts were reduced using a hydrogen $\left(5 \% \mathrm{H}_{2} / \mathrm{Ar}\right)$ and a temperature range of 100 to $700^{\circ} \mathrm{C}$ at a ramp rate of $10^{\circ} \mathrm{C} / \mathrm{min}$.

\subsection{Catalytic performance:}

The catalytic reduction was performed in an Inconel tubular reactor (length $500 \mathrm{~mm}$ x ID $12 \mathrm{~mm}$ ), as shown in Figure 1. The composition of gases used was $1000 \mathrm{ppm} \mathrm{NO}, 1000 \mathrm{ppm} \mathrm{NH}_{3}, 6 \mathrm{vol} \% \mathrm{O}_{2}$ and flows into the reactor with $100 \mathrm{ml} \mathrm{min}{ }^{-1}$, corresponding to gas hour space velocity (GHSV) of $13000 \mathrm{~h}^{-1}$. The mass flow controller (Bronkhorst) were used to control the gas flow rate. The thermocouple, connected to the PID controller and inserted inside the reactor was used to monitor the reaction temperature. For the catalytic test, the reaction temperature was performed in the range of $50-500^{\circ} \mathrm{C}$, and product gases were analyzed by NO 
analyzer (UNIPHOS ENVIROTRONIC Pvt Ltd, India) and gas chromatography (Centurion Scintific,5800 model). The activity and selectivity measurements were done based on the equations (3) and (4) as given below:

NO conversion $(\%)=\left(\frac{\mathrm{NO}_{\text {in }}-\mathrm{NO}_{\text {out }}}{\mathrm{NO}_{\text {in }}}\right) \times 100 \%(3)$

$\mathrm{N}_{2}$ selectivity $\left.(\%)=\left(\frac{N_{2}}{\mathrm{NO}_{\text {in }}-\mathrm{NO}_{\text {out }}}\right)\right) \times 100(4)$

FIGURE 1. Schematic diagram of $\mathrm{NH}_{3}$-SCR experimental setup

\section{RESULTS AND DISCUSSION}

\section{XRD}

The XRD pattern of $\mathrm{CeO}_{2}-\mathrm{NR}, \mathrm{CeO}_{2}-\mathrm{NP}, \mathrm{CeO}_{2}-\mathrm{NC}, \mathrm{Mn}_{2} \mathrm{O}_{3}, \mathrm{Mn}_{2} \mathrm{O}_{3} / \mathrm{CeO}_{2}-\mathrm{NR}, \mathrm{Mn}_{2} \mathrm{O}_{3} / \mathrm{CeO}_{2}-\mathrm{NC}$, and $\mathrm{Mn}_{2} \mathrm{O}_{3} / \mathrm{CeO}_{2}$-NP are shown in Figure 2. The diffraction peaks observed at 28.360, 32.700, 47.130, 55.900, $58.730,69.150,76.410$ and 78.760 corresponding to (111), (200), (220), (311), (222), (400), (331) and (420) crystal plane of ceria respectively and it is cubic face-centered $(\mathrm{a}=\mathrm{b}=\mathrm{c}=5.412)$ (JCPDS 81,0792). In case of pure $\mathrm{Mn}_{2} \mathrm{O}_{3}$, the peaks at 23.1090, 32.9190, 38.2200, 45.090, 49.290, 55.120 and 65.800 corresponding to (211), (222), (400), (332), (431), (440), and (622) crystal planes respectively were observed, ascribing to cubic body-centered type crystal structures $(\mathrm{a}=\mathrm{b}=\mathrm{c}=9.420) \quad(\operatorname{JCPDS} 89,2809)^{2,9}$. It indicated that all samples are crystalline in nature. The average crystal size of supports and catalysts was calculated by the Scherrer equation and is shown in Table 2. $\mathrm{CeO}_{2}-\mathrm{NP}$ showed the smallest crystal size, whereas $\mathrm{CeO}_{2}-\mathrm{NR}_{\text {has }}$ the largest crystal size. The orders of crystal size of $\mathrm{CeO}_{2}$ morphology are as follows: $\mathrm{CeO}_{2}-\mathrm{NP}>\mathrm{CeO}_{2}-\mathrm{NC}>$ $\mathrm{CeO}_{2}-\mathrm{NR}$.

\section{Hosted file}

image1.emf available at https://authorea.com/users/441562/articles/542033-selectivecatalytic-reduction-of-nox-with-nh3-over-mn2o3-supported-with-different-morphologyof-ceo2-catalysts

FIGURE 2. XRD pattern of catalysts (A) $\mathrm{CeO}_{2}-\mathrm{NR}$, (B) $\mathrm{CeO}_{2}-\mathrm{NC}(\mathrm{C}), \mathrm{CeO}_{2}-\mathrm{NP}$

(D), $\mathrm{Mn}_{2} \mathrm{O}_{3} / \mathrm{CeO}_{2}-\mathrm{NR}$, (E) $\mathrm{Mn}_{2} \mathrm{O}_{3} / \mathrm{CeO}_{2}-\mathrm{NC}(\mathrm{F}), \mathrm{Mn}_{2} \mathrm{O}_{3} / \mathrm{CeO}_{2}-\mathrm{NP}$ and (G) $\mathrm{Mn}_{2} \mathrm{O}_{3}$ catalysts.

The impregnation of $\mathrm{Mn}_{2} \mathrm{O}_{3}$ over improved the crystal size of all the catalysts. It may be due to the shared cubic structure of $\mathrm{Mn}_{2} \mathrm{O}_{3}$ with ceria morphology. There are no diffraction peaks observed related to $\mathrm{Mn}_{2} \mathrm{O}_{3}$ in all the samples, shows that $\mathrm{Mn}_{2} \mathrm{O}_{3}$ is highly dispersed over the $\mathrm{CeO}_{2}$ supports ${ }^{8,11}$. The smaller crystal size is possibly associated with the high specific surface area as correlated with BET data.

TABLE 2. Crystal size of $\mathrm{CeO}_{2}, \mathrm{Mn}_{2} \mathrm{O}_{3}$ and $\mathrm{Mn}_{2} \mathrm{O}_{3} / \mathrm{CeO}_{2}$ Samples

\begin{tabular}{lll}
\hline Sample & Crystal size $(\mathbf{n m})$ & Average particle size $(\mathbf{n m})$ \\
\hline $\mathrm{CeO}_{2}-\mathrm{NR}$ & 12.2 & 55 \\
$\mathrm{CeO}_{2}-\mathrm{NC}$ & 11.2 & 35 \\
$\mathrm{CeO}_{2}-\mathrm{NP}$ & 07.4 & 11 \\
$\mathrm{Mn}_{2} \mathrm{O}_{3}$ & 35.2 & - \\
$\mathrm{Mn}_{2} \mathrm{O}_{3} / \mathrm{CeO}_{2}-\mathrm{NR}$ & 13.0 & 80 \\
$\mathrm{Mn}_{2} \mathrm{O}_{3} / \mathrm{CeO}_{2}-\mathrm{NC}$ & 12.4 & 77 \\
$\mathrm{Mn}_{2} \mathrm{O}_{3} / \mathrm{CeO}_{2}-\mathrm{NP}$ & 08.3 & 24 \\
\hline
\end{tabular}

\section{BET}

The specific surface area, pore size, and pore volume of the $\mathrm{Mn}_{2} \mathrm{O}_{3}$ impregnated on different $\mathrm{CeO}_{2}$ morphology are listed in Table 3. The specific surface area of $\mathrm{Mn}_{2} \mathrm{O}_{3} / \mathrm{CeO}_{2}-\mathrm{NR}, \mathrm{Mn}_{2} \mathrm{O}_{3} / \mathrm{CeO}_{2}-\mathrm{NC}$, and 
$\mathrm{Mn}_{2} \mathrm{O}_{3} / \mathrm{CeO}_{2}$ - $\mathrm{NP}$ are 22.699, 30.253, and $34.352 \mathrm{~m}^{2} / \mathrm{g}$, respectively. $\mathrm{Mn}_{2} \mathrm{O}_{3} / \mathrm{CeO}_{2}-\mathrm{NP}$ shows the highest specific surface area and pore volume compared to the other two catalysts, and this is due to its lower crystalline nature and lower average particle size, as also evident by XRD and SEM results described later. This shows that the cubic and rod arrangement of atoms of $\mathrm{CeO}_{2}$ are more compact compared to $\mathrm{CeO}_{2}-\mathrm{NP}$. The loading effect of $\mathrm{Mn}_{2} \mathrm{O}_{3}\left(5,10\right.$, and $15 \%$ ) over $\mathrm{CeO}_{2}$ is shown in Table 3. The $10 \mathrm{wt} \% \mathrm{Mn}_{2} \mathrm{O}_{3}$ over $\mathrm{CeO}_{2}$ shows more surface area and pore volume than 5 and $15 \mathrm{wt} \%$, this is maybe due to the combined effect of $\mathrm{CeO}_{2}$ and $\mathrm{Mn}_{2} \mathrm{O}_{3}$ 's properties ${ }^{11,23}$. But $15 \mathrm{wt} \%$ loading inhibits the surface property due to surface coverage of $\mathrm{CeO}_{2}$ by more $\mathrm{Mn}_{2} \mathrm{O}_{3}$ atoms.

TABLE 3. BET of $\mathrm{Mn}_{2} \mathrm{O}_{3} / \mathrm{CeO}_{2}$ catalyst

\begin{tabular}{llll}
\hline Sample & $\mathbf{S}_{\text {BET }}\left(\mathbf{m}^{2} / \mathbf{g}\right)$ & $\mathbf{V}_{\text {total }}\left(\mathbf{c m}^{\mathbf{3}} / \mathbf{g}\right)$ & Pore size $(\mathbf{n m})$ \\
\hline $10 \mathrm{wt} \% \mathrm{Mn}_{2} \mathrm{O}_{3} / \mathrm{CeO}_{2}-\mathrm{NR}$ & 22.69 & 0.126 & 8.76 \\
$10 \mathrm{wt} \% \mathrm{Mn}_{2} \mathrm{O}_{3} / \mathrm{CeO}_{2}-\mathrm{NC}$ & 30.45 & 0.211 & 6.51 \\
$10 \mathrm{wt} \% \mathrm{Mn}_{2} \mathrm{O}_{3} / \mathrm{CeO}_{2}-\mathrm{NP}$ & 34.53 & 0.290 & 5.73 \\
$5 \mathrm{wt} \% \mathrm{Mn}_{2} \mathrm{O}_{3} / \mathrm{CeO}_{2}-\mathrm{NP}$ & 31.23 & 0.270 & 6.32 \\
$15 \mathrm{wt} \% \mathrm{Mn}_{2} \mathrm{O}_{3} / \mathrm{CeO}_{2}-\mathrm{NP}$ & 29.57 & 0.257 & 6.87 \\
\hline
\end{tabular}

\subsection{XPS}

The elements that exist within a material (elemental composition) are covering its surface and oxidation states in the material were identified using X-ray photoelectron spectroscopy (XPS), with the spectrum of this study shown in Figure 3.

The Ce 3d spectra of the catalysts are shown in Figure 3 (A). All catalysts were de-convoluted into six peaks, which were represented as $u^{\circ}, u^{i}, u^{i i}, v^{\circ}, v^{i}$, and $v^{i i}$. The spin-orbit doublet peak's series represented by $\mathrm{u}$ and $\mathrm{v}$ respectively denote the Ce $3 \mathrm{~d} 3 / 2$, and Ce $3 \mathrm{~d} 5 / 2$ states. According to analyzed catalysts, it was found that both $\mathrm{Ce}^{3+}$ and $\mathrm{Ce}^{4+}$ ions are dispersed in the catalysts. In these peaks $\mathrm{u}^{\circ}(901.48 \mathrm{eV})$, and vdeg $(883.29 \mathrm{eV})$ are ascribed to $\mathrm{Ce}^{3+}$ ions XPS peaks, while $\mathrm{u}^{\mathrm{i}}(907.78 \mathrm{eV}), \mathrm{u}^{\mathrm{ii}}(917.18 \mathrm{eV}), \mathrm{v}^{\mathrm{i}}(888.88 \mathrm{eV})$ and $\mathrm{v}^{\text {ii }}(897.88 \mathrm{eV})$ are ascribed to $\mathrm{Ce}^{4+}$ ions species

29. De-convoluted split peaks confirm the presence of $\mathrm{Ce}^{3+}$ and $\mathrm{Ce}^{4+}$ ions in the $\mathrm{CeO}_{2}$ oxides. The proportion of lattice oxygen and surface ion contents of $\mathrm{Ce}^{3+}$ had a significant effect on the performance of the catalyst. The percentage evaluation of $\mathrm{Ce}^{3+}$ state is calculated as,

$\mathrm{Ce}^{3+} \%=\left(\frac{\mathrm{Ce}^{3+}}{\mathrm{Ce}^{3+}+\mathrm{Ce}^{4+}}\right) \times 100(5)$

Table 4 shows that $\mathrm{Mn}_{2} \mathrm{O}_{3} / \mathrm{CeO}_{2}$-NP had the highest $\mathrm{Ce}^{3+}$ concentration among all particle-base catalysts. 

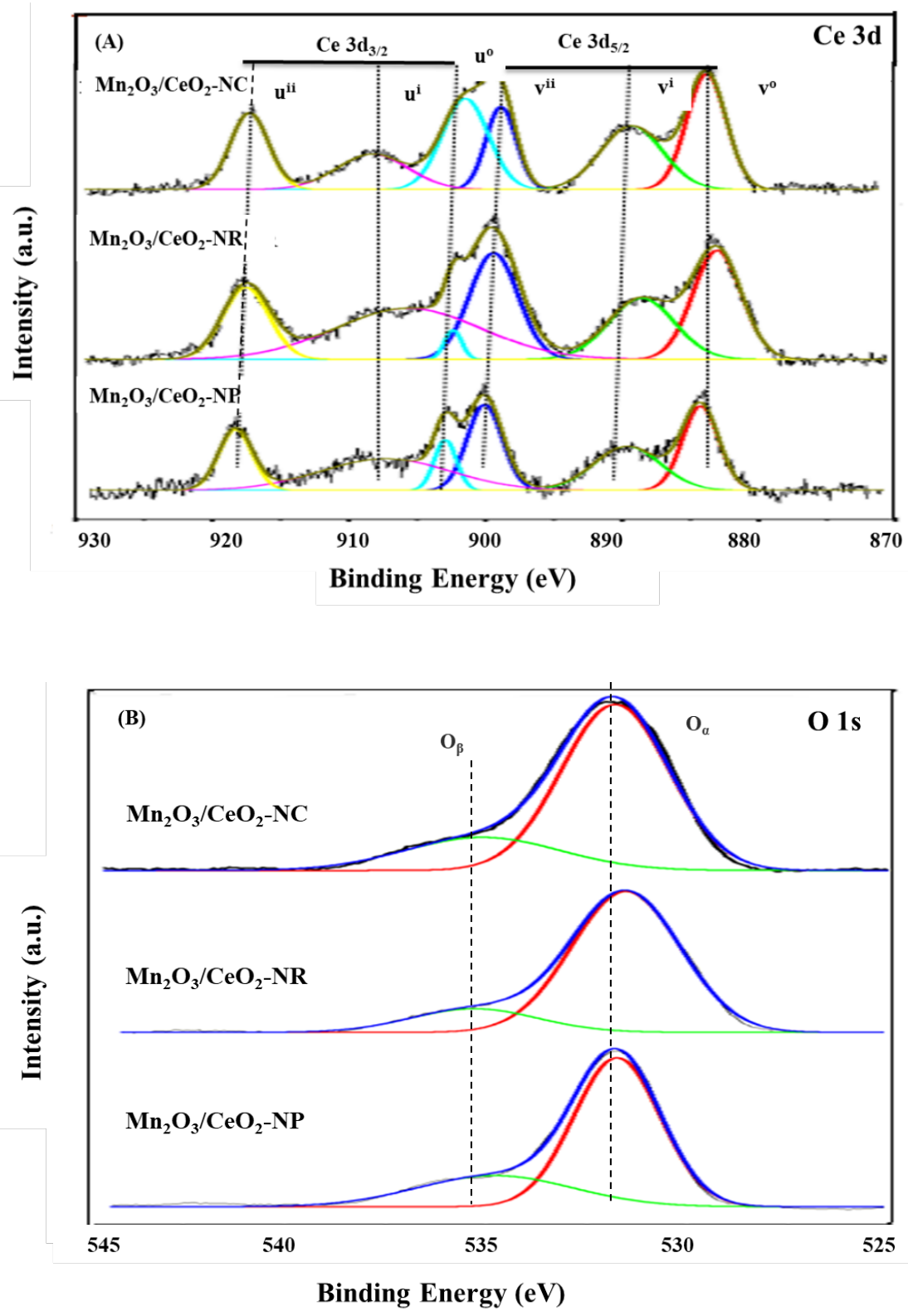


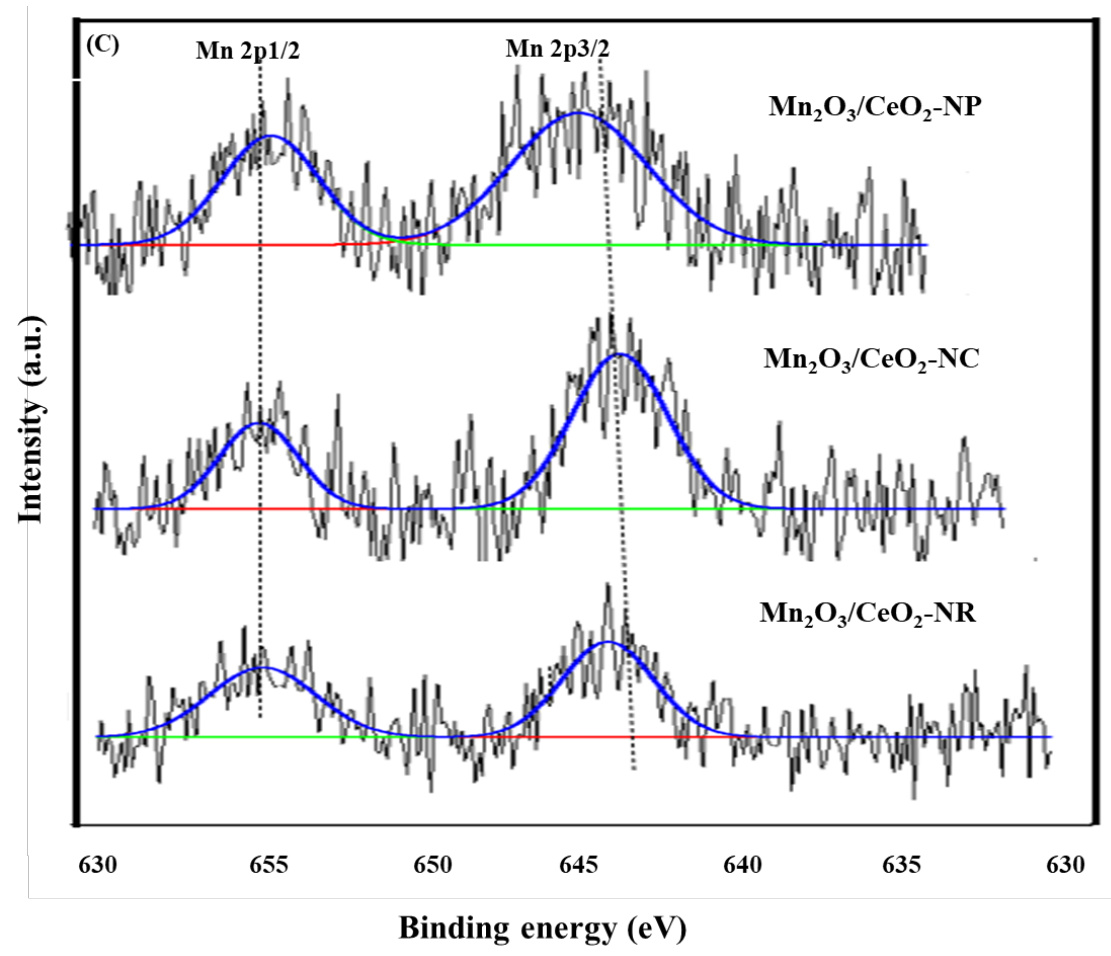

FIGURE 3. XPS spectra of (A) Ce 3d, (B) O 1s, and (C) Mn 2p catalysts.

TABLE 4 . Atomic ratios of the catalysts by XPS spectra

\begin{tabular}{llll}
\hline Catalysts & $\left(\frac{\mathbf{C e}^{3+}}{\mathbf{C e}^{3+}+\mathbf{C e}^{4+}}\right)$ & $\left(\frac{\mathbf{O}_{\alpha}}{\mathbf{O}_{\alpha}+\mathbf{O}_{\beta}}\right)$ & $\left(\frac{\mathbf{M n}^{4+}}{\mathbf{M n}^{4+}+\mathbf{M n}^{3+}}\right)$ \\
\hline $\mathrm{Mn}_{2} \mathrm{O}_{3} / \mathrm{CeO}_{2}-\mathrm{NR}$ & 0.3896 & 0.7022 & 0.7156 \\
$\mathrm{Mn}_{2} \mathrm{O}_{3} / \mathrm{CeO}_{2}-\mathrm{NP}$ & 0.4353 & 0.7331 & 0.7621 \\
$\mathrm{Mn}_{2} \mathrm{O}_{3} / \mathrm{CeO}_{2}-\mathrm{NC}$ & 0.4102 & 0.7276 & 0.7431 \\
\hline
\end{tabular}

The de-convoluted $\mathrm{O}$ 1s spectra of $\mathrm{Mn}_{2} \mathrm{O}_{3} / \mathrm{CeO}_{2}$ catalysts show two peaks marked as $\mathrm{O}_{\alpha}$ and $\mathrm{O}_{\beta}$, respectively, as shown in Figure 3(B). The first one is caused by lattice oxygen species, whereas second is caused by chemisorbed oxygen ${ }^{14,16,29}$. It is widely known that chemisorbed adsorb oxygen on defective catalyst sites has a high migratory potential, which helps in oxidization ${ }^{3,5,6}$. The relative concentration of $\mathrm{O}_{\alpha}\left(\mathrm{O}_{\alpha} /\left(\mathrm{O}_{\alpha}\right.\right.$ $+\mathrm{O}_{\beta}$ ) is calculated, and are shown in Table 4. The Oxygen content of $\mathrm{Mn}_{2} \mathrm{O}_{3} / \mathrm{CeO}_{2}$ catalysts is ranked as: $\mathrm{Mn}_{2} \mathrm{O}_{3} / \mathrm{CeO}_{2}-\mathrm{NP}>\mathrm{Mn}_{2} \mathrm{O}_{3} / \mathrm{CeO}_{2}-\mathrm{NC}>\mathrm{Mn}_{2} \mathrm{O}_{3} / \mathrm{CeO}_{2}-\mathrm{NR}$. It is implying that $\mathrm{Mn}_{2} \mathrm{O}_{3} / \mathrm{CeO}_{2}-\mathrm{NR}$ has the more chemisorbed oxygen species.

As seen in Figure3(C), the Mn 2p region consists of two peaks, Mn 2p3/2 with binding energy (BE) of approximately $643.7 \mathrm{eV}$ and $\mathrm{Mn} 2 \mathrm{p} 1 / 2$ with a binding energy of about $655.3 \mathrm{eV}$ which are made up of $\mathrm{Mn}^{4+}$ and $\mathrm{Mn}^{3+}$, indicating that $\mathrm{Mn}$ is in the mixed-valence state that is in $\mathrm{Mn}^{3+}$ and $\mathrm{Mn}^{4+}$ form ${ }^{30,31,32}$. For three catalysts, the $\mathrm{Mn}^{3+} /\left(\mathrm{Mn}^{3+}+\mathrm{Mn}^{4+}\right)$ content ratio is calculated and found that $\mathrm{Mn}_{2} \mathrm{O}_{3} / \mathrm{CeO}_{2}-\mathrm{NP}$ has highest $\mathrm{Mn}^{4+}$ contents. The $\mathrm{Mn}^{4+}$ is catalyst's primary valence that play substantial role in the reduction reaction ${ }^{30}$.

\subsection{TEM}

TEM characterization is used to analyze the morphology structures and average particle size of synthe- 
sized $\mathrm{CeO}_{2}-\mathrm{NR}, \mathrm{CeO}_{2}-\mathrm{NP}$, and $\mathrm{CeO}_{2}-\mathrm{NC}$ and $\mathrm{Mn}_{2} \mathrm{O}_{3} / \mathrm{CeO}_{2}-\mathrm{NR}, \mathrm{Mn}_{2} \mathrm{O}_{3} / \mathrm{CeO}_{2}-\mathrm{NP}$, and $\mathrm{Mn}_{2} \mathrm{O}_{3} / \mathrm{CeO}_{2}-\mathrm{NC}$ catalysts. Figure 4 showed that the hydrothermal approach successfully synthesizes $\mathrm{CeO}_{2}$ supported morphologies such as $\mathrm{CeO}_{2}-\mathrm{NR}, \mathrm{CeO}_{2}-\mathrm{NC}$, and $\mathrm{CeO}_{2}-\mathrm{NP}^{33,34}$. It exhibited that after impregnating $\mathrm{Mn}_{2} \mathrm{O}_{3}$ over $\mathrm{CeO}_{2}$ supports, all supports kept their original morphologies (Figure 4.D, E, and F), as confirmed by the SEM and EDX data. This shows that the $\mathrm{Mn}_{2} \mathrm{O}_{3}$ is dispersed over $\mathrm{CeO}_{2}$ morphology-based supports. The textural parameters of all catalysts are shown in Table 3. The $\mathrm{Mn}_{2} \mathrm{O}_{3} / \mathrm{CeO}_{2}$ - $\mathrm{NP}$ sample had the smallest average particle size and the highest surface area out of the three catalysts, making it potentially beneficial for the $\mathrm{NH}_{3}-\mathrm{SCR}$ reaction, followed by $\mathrm{Mn}_{2} \mathrm{O}_{3} / \mathrm{CeO}_{2}-\mathrm{NR}$ and $\mathrm{Mn}_{2} \mathrm{O}_{3} / \mathrm{CeO}_{2}-\mathrm{NC}$. The particle size of $\mathrm{Mn}_{2} \mathrm{O}_{3} / \mathrm{CeO}_{2}-\mathrm{NP}$ is the highest, while the specific surface area is the smallest; it shows a correlation of BET surface area with TEM particle size data.
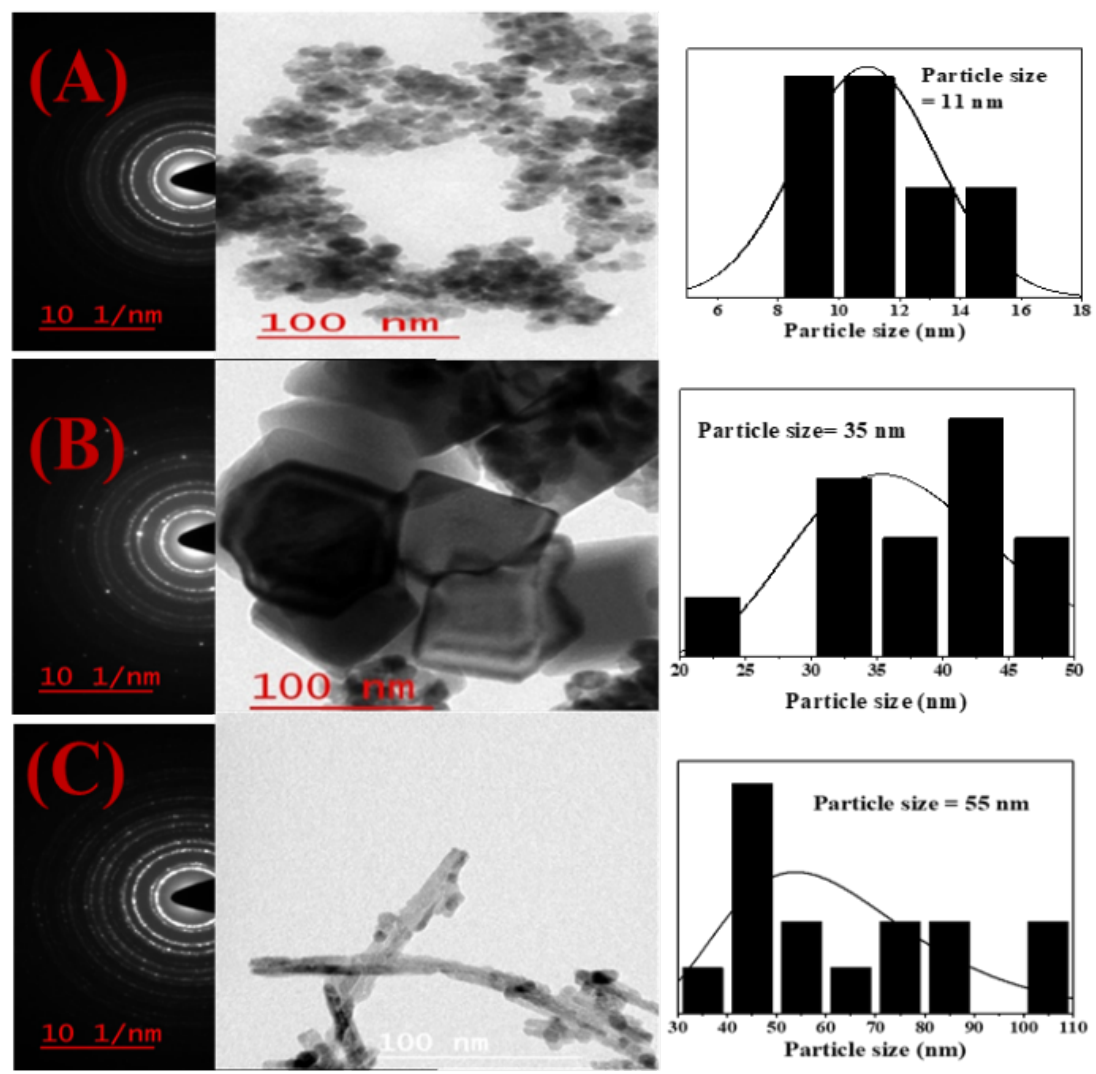

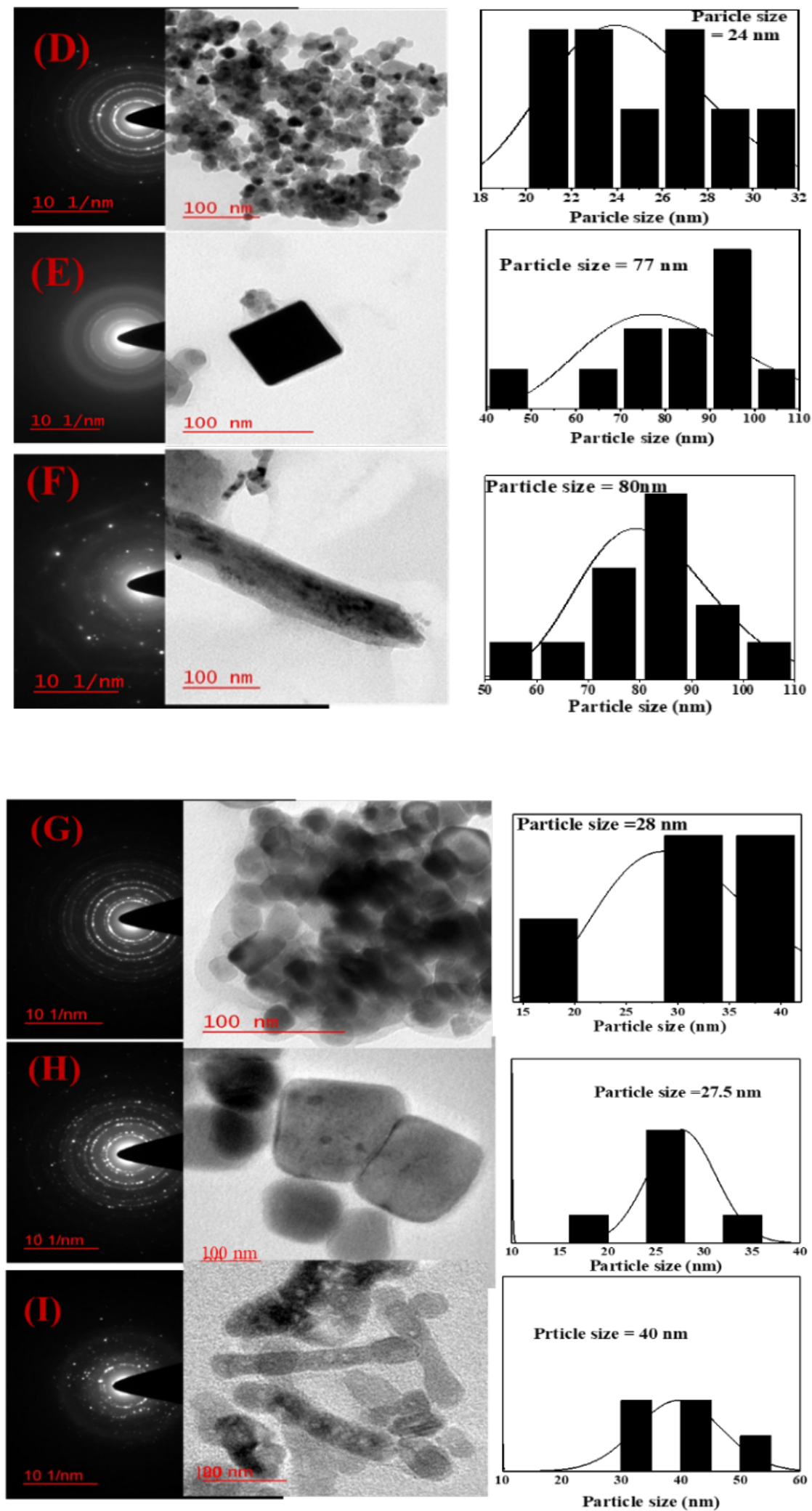
FIGURE 4 . TEM images of supports, catalysts, and used catalysts (A) $\mathrm{CeO}_{2}-\mathrm{NP}$, (B) $\mathrm{CeO}_{2}-\mathrm{NC}$, (C) $\mathrm{CeO}_{2}-\mathrm{NR}$, (D) $\mathrm{Mn}_{2} \mathrm{O}_{3} / \mathrm{CeO}_{2}-\mathrm{NP},(\mathrm{E}), \mathrm{Mn}_{2} \mathrm{O}_{3} / \mathrm{CeO}_{2}-\mathrm{NC}$, (F) $\mathrm{Mn}_{2} \mathrm{O}_{3} / \mathrm{CeO}_{2}-\mathrm{NR}$,

(G) $\mathrm{Mn}_{2} \mathrm{O}_{3} / \mathrm{CeO}_{2}-\mathrm{NP},(\mathrm{H}) \mathrm{Mn}_{2} \mathrm{O}_{3} / \mathrm{CeO}_{2}-\mathrm{NC}$, and (I) $\mathrm{Mn}_{2} \mathrm{O}_{3} / \mathrm{CeO}_{2}-\mathrm{NR}$

\subsection{SEM-EDX}

The SEM and EDX images of $\mathrm{CeO}_{2}-\mathrm{NR}, \mathrm{CeO}_{2}-\mathrm{NC}$, and $\mathrm{CeO}_{2}-\mathrm{NP}$ and catalysts: $\mathrm{Mn}_{2} \mathrm{O}_{3} / \mathrm{CeO}_{2}-\mathrm{NR}$, $\mathrm{Mn}_{2} \mathrm{O}_{3} / \mathrm{CeO}_{2}-\mathrm{NP}$, and $\mathrm{Mn}_{2} \mathrm{O}_{3} / \mathrm{CeO}_{2}-\mathrm{NC}$ synthesized by the wet-impregnation method shown in Figure 5. Comparing the SEM images of all catalysts and their supports, it is clear that $\mathrm{Mn}_{2} \mathrm{O}_{3}$ is impregnated over the supports and also confirmed in EDX data $(\mathrm{C}),(\mathrm{F})$, and (I). Comparing $\mathrm{B}, \mathrm{E}$, and $\mathrm{H}$, it can be found that impregnation of $\mathrm{Mn}_{2} \mathrm{O}_{3}$ over $\mathrm{CeO}_{2}-\mathrm{NP}$ made the morphology of $\mathrm{CeO}_{2}-\mathrm{NP}$ more homogeneous and thus showing the high dispersion of active components $\left(\mathrm{Mn}_{2} \mathrm{O}_{3}\right)$ over the surface of $\mathrm{CeO}_{2}-\mathrm{NP}$. It is observed that $\mathrm{Mn}_{2} \mathrm{O}_{3} / \mathrm{CeO}_{2}-\mathrm{NP}$ and $\mathrm{Mn}_{2} \mathrm{O}_{3} / \mathrm{CeO}_{2}-\mathrm{NC}$ have less roughness and un-uniformity compared with $\mathrm{Mn}_{2} \mathrm{O}_{3} / \mathrm{CeO}_{2}-\mathrm{NR}$. The surface got rougher, thereby increasing the catalyst's specific surface area and providing additional reaction sites. BET and TEM data confirmed that $\mathrm{Mn}_{2} \mathrm{O}_{3} / \mathrm{CeO}_{2}-\mathrm{NP}$ has a high surface area and a homogeneous distribution of $\mathrm{Mn}_{2} \mathrm{O}_{3}$.

\section{$5.6 \mathrm{H}_{2}$-TPR}

$\mathrm{H}_{2}$-TPR of the samples are shown in Figure 6. Nano-rod shape of $\mathrm{CeO}_{2}$ shows the slightly higher reduction temperature (360 and 450 ) compared to Nano-particle (298 and 400 ) and Nano-cube $\mathrm{CeO}_{2}$ (295 and 402). It is related to the reduction of surface $\mathrm{Ce}^{4+}$ to $\mathrm{Ce}^{3+}$. At low temperatures, $\mathrm{CeO}_{2}-\mathrm{NR}$ had weaker reduction peaks than $\mathrm{CeO}_{2}-\mathrm{NC}$ and $\mathrm{CeO}_{2}-\mathrm{NP}$ subsequently, indicating weaker redox capability. It shows that the atoms in Nano-rod arranged more strongly than the cube and particle state of $\mathrm{CeO}_{2}$, show more peaks area and hence more hydrogen consumption in reduction ${ }^{12}$. The reduction peaks at low temperature shifted to higher temperature after the impregnation of $10 \mathrm{wt} \% \mathrm{Mn}_{2} \mathrm{O}_{3}$ over Ceria's morphology-based support. The $\mathrm{Mn}_{2} \mathrm{O}_{3}$ state shows two reduction peaks at 421 and 519, and both are higher than Ceria with broader peaks. It can shift the reduction performance of catalyst over 350, with broadening the range. 


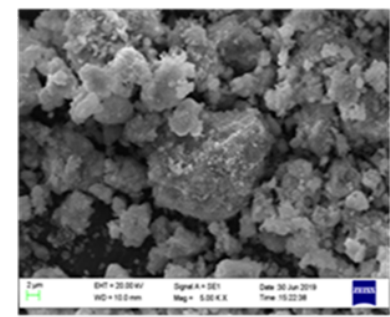

(A) $\mathrm{CeO}_{2}-\mathrm{NR}$

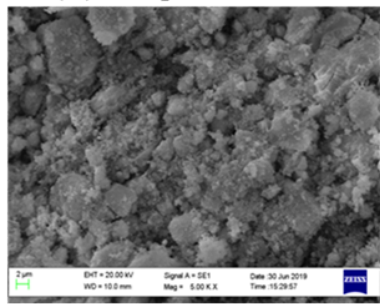

(D) $\mathrm{CeO}_{2}-\mathrm{NC}$

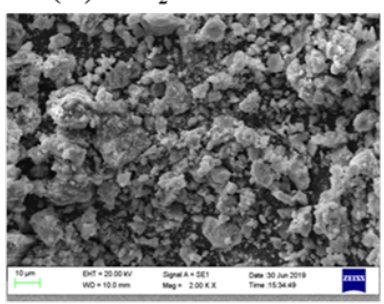

(G) $\mathrm{CeO}_{2}-\mathrm{NP}$

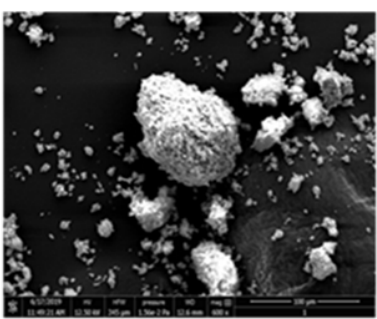

(B) $\mathrm{Mn}_{2} \mathrm{O}_{3} / \mathrm{CeO}_{2}-\mathrm{NR}$

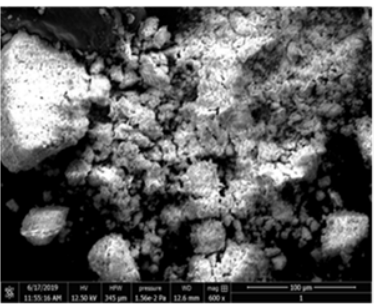

(E) $\mathrm{Mn}_{2} \mathrm{O}_{3} / \mathrm{CeO}_{2}-\mathrm{NC}$

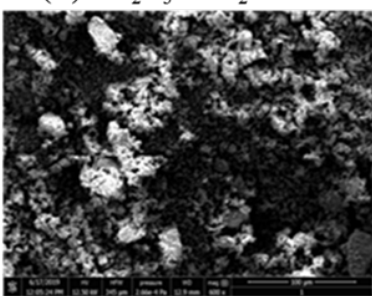

(H) $\mathrm{Mn}_{2} \mathrm{O}_{3} / \mathrm{CeO}_{2}-\mathrm{NP}$

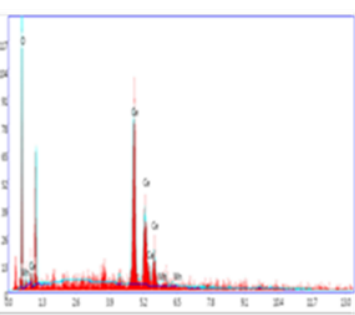

(C) $\mathrm{Mn}_{2} \mathrm{O}_{3} / \mathrm{CeO}_{2}-\mathrm{NR}$

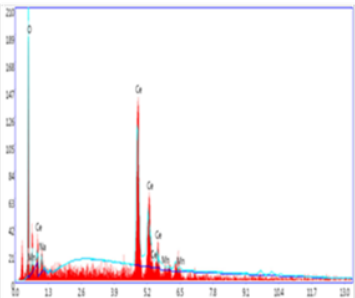

(F) $\mathrm{Mn}_{2} \mathrm{O}_{3} / \mathrm{CeO}_{2}-\mathrm{NC}$

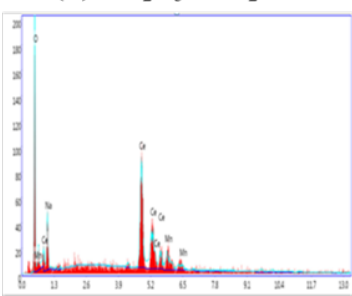

(I) $\mathrm{Mn}_{2} \mathrm{O}_{3} / \mathrm{CeO}_{2}-\mathrm{NP}$

FIGURE 5. SEM and EDX images of $\mathrm{CeO}_{2}$ supports and $\mathrm{Mn}_{2} \mathrm{O}_{3} / \mathrm{CeO}_{2}$ catalysts

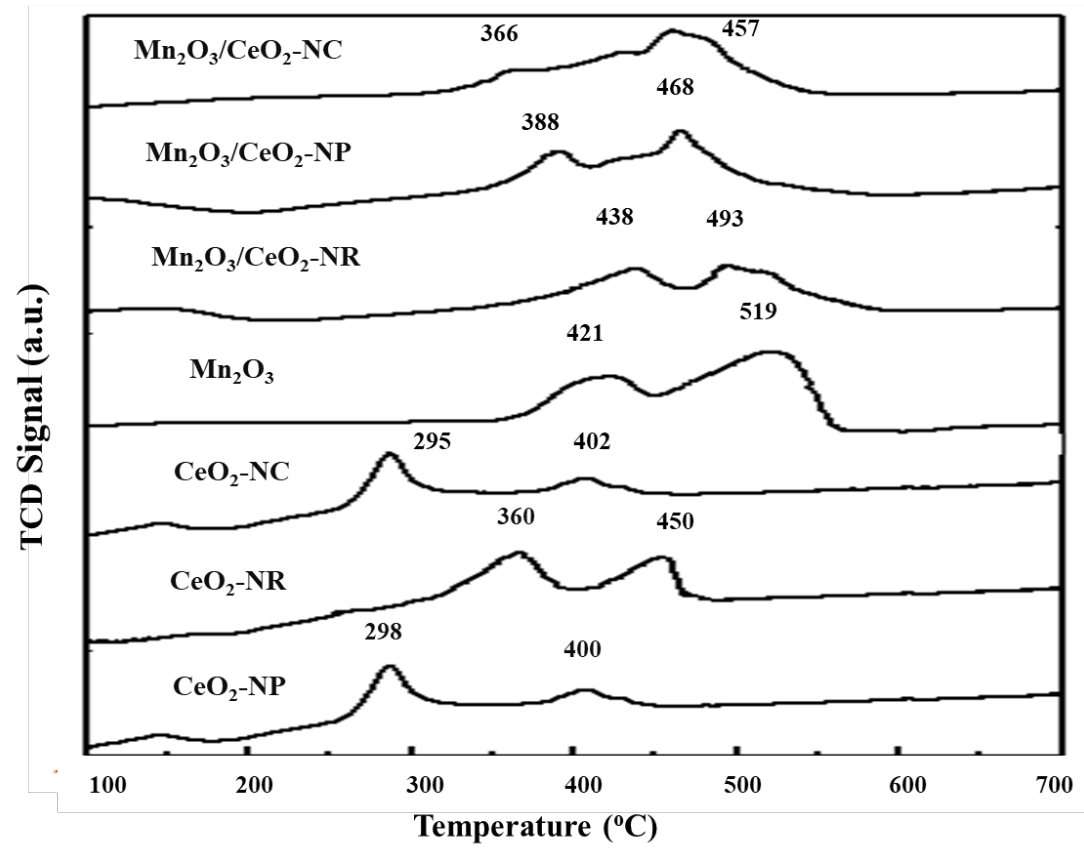


FIGURE 6. $\mathrm{H}_{2}$-TPR profile $\mathrm{Mn}_{2} \mathrm{O}_{3}, \mathrm{CeO}_{2}-\mathrm{NR}, \mathrm{Mn}_{2} \mathrm{O}_{3} / \mathrm{CeO}_{2}-\mathrm{NR}, \mathrm{CeO}_{2}-\mathrm{NC}, \mathrm{Mn}_{2} \mathrm{O}_{3} / \mathrm{CeO}_{2}-\mathrm{NC}, \mathrm{CeO}_{2}$ $\mathrm{NP}, \mathrm{Mn}_{2} \mathrm{O}_{3} / \mathrm{CeO}_{2}-\mathrm{NP}$

\subsection{Catalytic Performance and Discussion}

\subsubsection{NO catalytic activity}

The NOx conversion activity and $\mathrm{N}_{2}$ selectivity of $10 \mathrm{wt} \% \mathrm{Mn}_{2} \mathrm{O}_{3}$ based $\mathrm{CeO}_{2}$ morphology of $\mathrm{NP}$, NR, and $\mathrm{NC}$ catalysts in temperature range of $50-450$ are in figure 7 . Figure $7(\mathrm{~A})$ shows the $\mathrm{NH}_{3}$-SCR activity of $\mathrm{Mn}_{2} \mathrm{O}_{3} / \mathrm{CeO}_{2}$ catalysts at various temperatures. The morphologies of $\mathrm{CeO}_{2}$ catalyst regulate the $\mathrm{NOx}$ reduction performance of $\mathrm{NH}_{3}$-SCR. NOx conversion was done in the following order at temperatures below $350^{\circ} \mathrm{C} ; \mathrm{Mn}_{2} \mathrm{O}_{3} / \mathrm{CeO}_{2}-\mathrm{NP}>\mathrm{Mn}_{2} \mathrm{O}_{3} / \mathrm{CeO}_{2}-\mathrm{NC}>\mathrm{Mn}_{2} \mathrm{O}_{3} / \mathrm{CeO}_{2}-\mathrm{NC}$. The $\mathrm{Mn}_{2} \mathrm{O}_{3} / \mathrm{CeO}_{2}-\mathrm{NP}$ catalyst has the maximum $\mathrm{NH}_{3}$-SCR activity, with a $\mathrm{NOx}$ conversion of about $76.03 \%$ at $100-450^{\circ} \mathrm{C}$. Even though all $\mathrm{Mn}_{2} \mathrm{O}_{3} / \mathrm{CeO}_{2}$ catalysts had the same $\mathrm{Mn}_{2} \mathrm{O}_{3}$ loadings, $\mathrm{NH}_{3}$-SCR catalytic efficiency depended on $\mathrm{CeO}_{2}$ morphology. $\mathrm{Mn}_{2} \mathrm{O}_{3} / \mathrm{CeO}_{2}$-NP catalysts showed the highest $\mathrm{NOx}$ conversion activity above $300^{\circ} \mathrm{C}$ due to the more BET surface area and pore volume and caused significant active sites and response time for reaction. One other reason is the XPS deconvolution data of $\mathrm{Mn}_{2} \mathrm{O}_{3} / \mathrm{CeO}_{2}-\mathrm{NP}$ catalysts show an excellent quantity of $\mathrm{Ce}^{3+}$, adsorbed oxygen, and $\mathrm{Mn}^{4+}$ states in $\mathrm{Mn}_{2} \mathrm{O}_{3} / \mathrm{CeO}_{2}$ - $\mathrm{NP}$ catalysts; 0.4353 , 0.733 , and 0.7621 , respectively.

The figure $7(\mathrm{~B})$ shows the $\mathrm{N}_{2}$ selectivity profile of catalysts. It can be observed that the $\mathrm{N}_{2}$ selectivity is approximate follow the $\mathrm{NO}_{\mathrm{x}}$ conversion profile of catalysts. At lower temperatures, it shows very little activity as like selectivity. These surface properties are helpful in ammonia adsorption and further $\mathrm{NO}_{\mathrm{x}}$ reduction. Among all three catalysts, $\mathrm{Mn}_{2} \mathrm{O}_{3} / \mathrm{CeO}_{2}-\mathrm{NP}$ showed the best $\mathrm{NO}_{\mathrm{x}}$ conversion shown in figure 7 .

\subsubsection{Effect of $\mathrm{Mn}_{2} \mathrm{O}_{3}$ loading on $\mathrm{NH}_{3}$-SCR performance}

It is well known that the activity of the catalyst is the function of active sites of loaded metals and support. Here, to optimize the loading, prepared the 5, 10, and 15 wt. $\% \mathrm{Mn}_{2} \mathrm{O}_{3}$ over $\mathrm{CeO}_{2}-\mathrm{NP}$. The 10 wt\% $\mathrm{Mn}_{2} \mathrm{O}_{3} / \mathrm{CeO}_{2}$-NP shows the highest $\mathrm{NO}_{\mathrm{x}}$ conversion activity and $\mathrm{N} 2$ selectivity approx. $78 \%$ and $84 \%$ at 350. This may be due to more active surface area and required pore volume for the $\mathrm{NO}_{\mathrm{x}}$ reduction to $\mathrm{N}_{2}$ conversion. At 5 and $15 \mathrm{wt} \%$ loading, there are less active sites for $\mathrm{NO}_{\mathrm{x}}$ conversion may be due to fewer $\mathrm{Mn}_{2} \mathrm{O}_{3}$ or presence in cluster form and hence insignificant for the reaction. The $15 \mathrm{wt} \% \mathrm{Mn}_{2} \mathrm{O}_{3} / \mathrm{CeO}_{2}-\mathrm{NP}$ shows the highest $\mathrm{N}_{2}$ selectivity compared to 5 and $10 \mathrm{wt} \% \mathrm{Mn}_{2} \mathrm{O}_{3}$ loading over $\mathrm{CeO}_{2}-\mathrm{NP}$. There is no clear information about this, but it may be due to the required BET surface area, pore-volume, and other chemical properties of catalysts. 
(A)

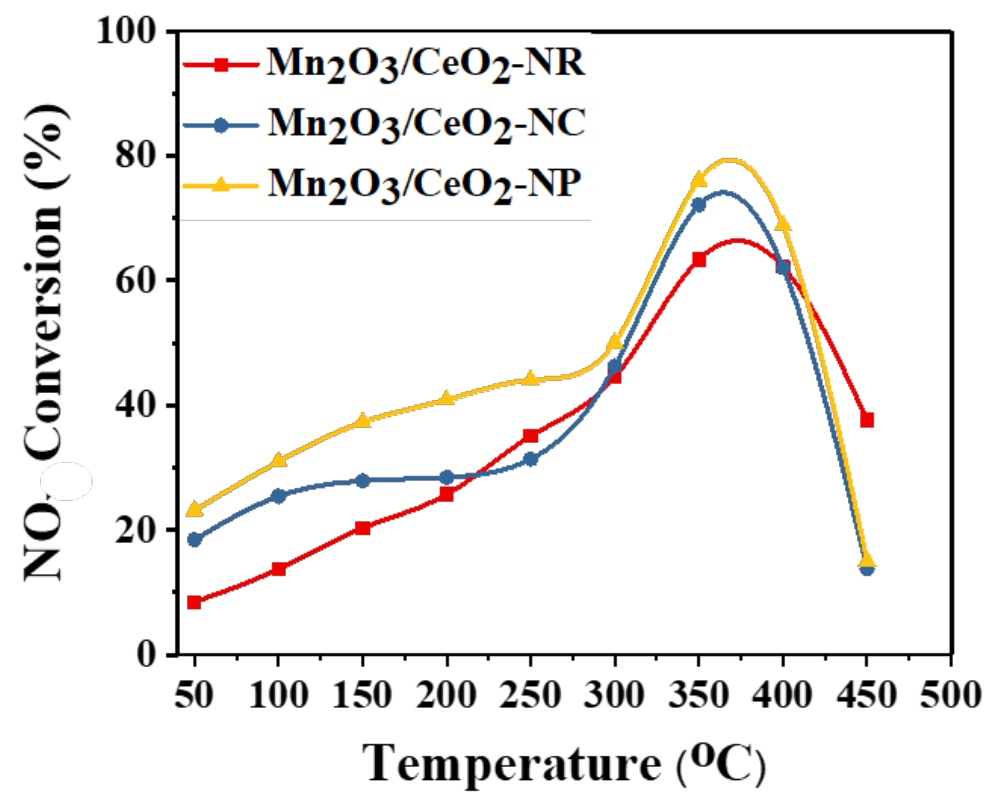

(B)

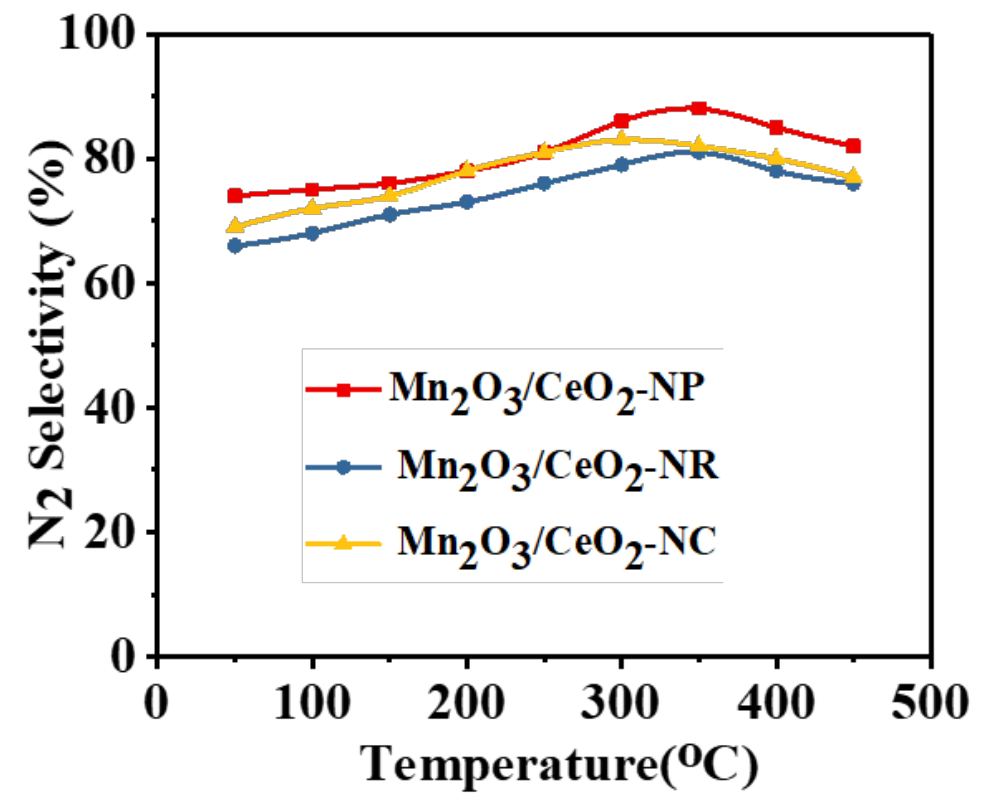

FIGURE 7. NO conversion at temperature range 50 to $450^{\circ} \mathrm{C}$. Reaction conditions: $\mathrm{NO}, \mathrm{NH}_{3}=1000 \mathrm{ppm}$, $\mathrm{O}_{2}=6 \mathrm{vol} \%, \mathrm{~N}_{2}$ balance, and GHSV $=13,000 \mathrm{~h}^{-1}$ 
(A)

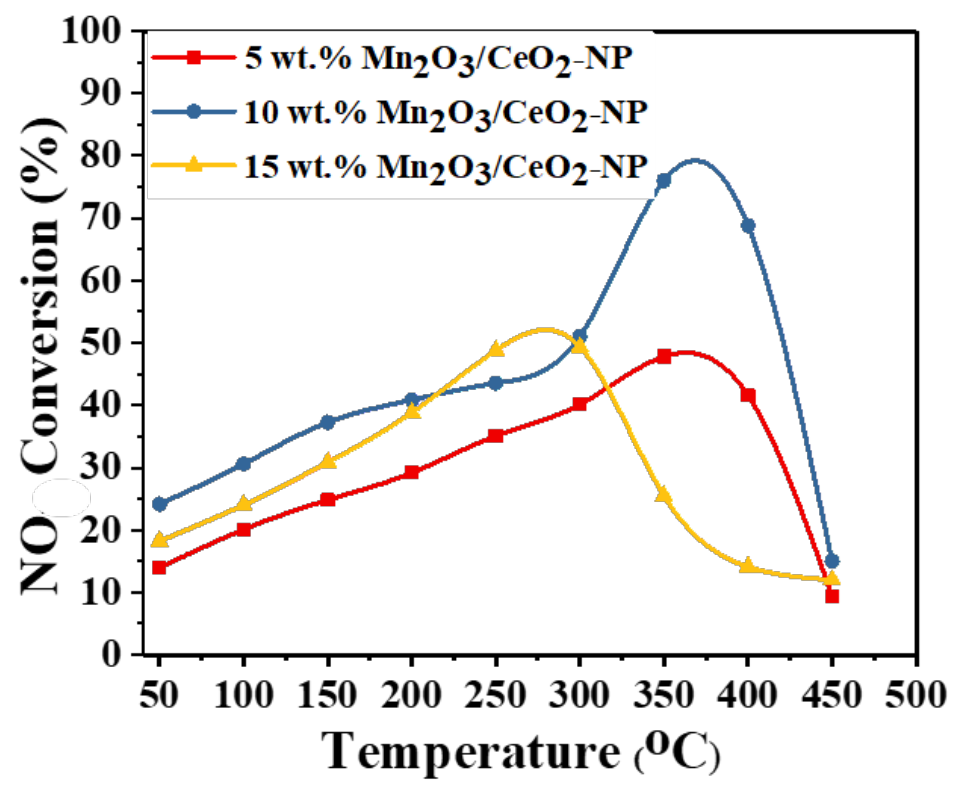

(B)

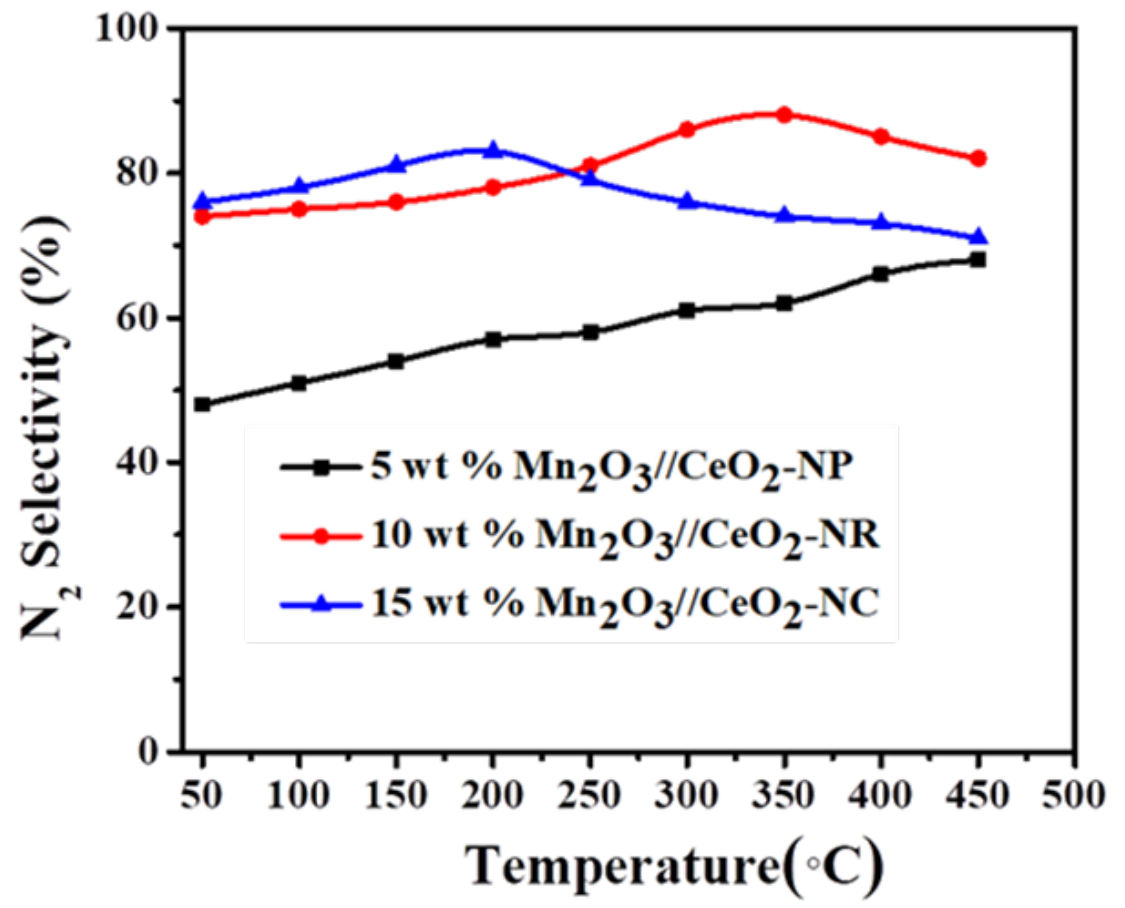

FIGURE 8. $\mathrm{NO}$ conversion at temperature range 50 to $450^{\circ} \mathrm{C}$. Reaction conditions: $\mathrm{NO}, \mathrm{NH}_{3}=1000 \mathrm{ppm}$, $\mathrm{O}_{2}=6 \operatorname{vol} \%, \mathrm{~N}_{2}$ balance, and GHSV $=13,000 \mathrm{~h}^{-1}$ 


\section{CONCLUSIONS}

The effect of bare $\mathrm{CeO}_{2}$ support with varied morphology and metal-support interaction in $\mathrm{Mn}_{2} \mathrm{O}_{3} / \mathrm{CeO}_{2}$ based catalysts for $\mathrm{NH}_{3}$-SCR of $\mathrm{NO}$ has been studied. The $\mathrm{Mn}_{2} \mathrm{O}_{3} / \mathrm{CeO}_{2}-\mathrm{NP}$ catalyst synthesized showed the highest catalytic performance among the other $\mathrm{Mn}_{2} \mathrm{O}_{3} / \mathrm{CeO}_{2}-\mathrm{NR}, \mathrm{Mn}_{2} \mathrm{O}_{3} / \mathrm{CeO}_{2}-\mathrm{NP}$, and $\mathrm{Mn}_{2} \mathrm{O}_{3} / \mathrm{CeO}_{2^{-}}$ $\mathrm{NC}$ catalysts, with around $76.03 \% \mathrm{NO}$ conversion at $50-450^{\circ} \mathrm{C}$. The lowest crystal size of $\mathrm{Mn}_{2} \mathrm{O}_{3} / \mathrm{CeO}_{2}-\mathrm{NP}$ $(8.3 \mathrm{~nm})$ and the highest specific surface area $\left(34.53 \mathrm{~m}^{2} / \mathrm{gm}\right)$, facilitated the better dispersion $\mathrm{Mn}_{2} \mathrm{O}_{3}$ species $\left(\mathrm{Mn}^{4+}=76.21 \%\right)$ and creation of more surface defects. As a result, $\mathrm{Mn}_{2} \mathrm{O}_{3} / \mathrm{CeO}_{2}-\mathrm{NP}$ exhibited very high surface oxygen content (73.31\%) and appreciable redox capacity as evident by XPS and $\mathrm{H}_{2}$-TPR analysis. Thus, it is concluded favourable morphology of the support led to the desirable interaction with the metal, exhibiting support morphology effect on metal. In addition, the use of $\mathrm{CeO}_{2}$ with $\mathrm{Mn}_{2} \mathrm{O}_{3}$ showed positive synergism, revealing desirable metal-support interaction system for $\mathrm{NO}_{\mathrm{x}}$ reduction by $\mathrm{NH}_{3} \mathrm{SCR}$ reaction.

\section{REFERENCES}

1. Chen J, Fu P, Lv D, Chen Y, Fan M, Wu J, Meshram A, Mu B, Li X, Xia Q. Unusual positive effect of $\mathrm{SO}_{2}$ on Mn-Ce mixed-oxide catalyst for the $\mathrm{SCR}$ reaction of $\mathrm{NO}_{\mathrm{x}}$ with $\mathrm{NH}_{3}$. Chem Eng J. 2021;407: 127071.

2. Yao X, Chen L, Cao J, Yang F, Tan W, Dong L. Morphology and Crystal-Plane Effects of $\mathrm{CeO}_{2}$ on $\mathrm{TiO}_{2} / \mathrm{CeO}_{2}$ Catalysts during $\mathrm{NH}_{3}$-SCR Reaction. Ind. Eng. Chem. Res. 2018; 57:12407-12419.

3. Xiao X, Xiong S, Li B, Geng Y, Yang S. Synthesis of $\mathrm{MoS}_{2} / \mathrm{g}-\mathrm{C}_{3} \mathrm{~N}_{4}$ nanocomposites with enhanced visible-light photocatalytic activity for the removal of nitric oxide (NO). Catal. Lett.2016;146:22422251

4. Ye Y, Zang Z, Zhou T, Dong F, Lu S, Tang X, Wei W, Zhang Y. Theoretical and experimental investigation of highly photocatalytic performance of CuInZnS nanoporous structure for removing the NO gas .J. Catal.2018;357:100-107.

5. Gao F, Tang X, Zaharaddeen S, Yi H, Zhao S, Yu Q, Shi Y, Zhou Y, Ni S. Spinel-structured Mn-Ni nanosheets for $\mathrm{NH}_{3}$-SCR of $\mathrm{NO}$ with good $\mathrm{H}_{2} \mathrm{O}$ and $\mathrm{SO}_{2}$ resistance at low temperature. Catal. Sci. Technol.2020; 10: 7486 .

6. Bendrich M, Scheuer A, Hayes R E, Votsmeier M. Unified mechanistic model for Standard SCR, Fast SCR, and $\mathrm{NO}_{2}$ SCR over a copper chabazite catalyst. Appl. Catal. B.2018; 222: 76-87.

7. Wen M Q, Xiong T, Zang Z G, Wei W, Tang X S, Dong F. Synthesis of $\mathrm{MoS}_{2} / \mathrm{g}-\mathrm{C}_{3} \mathrm{~N}_{4}$ nanocomposites with enhanced visible-light photocatalytic activity for the removal of nitric oxide (NO). Opt. Express.2016; 24:10205-10212.

8. Lian Z, Shan W, Zhang Y, Wang M, He H. Morphology-Dependent Catalytic Performance of $\mathrm{NbO}_{\mathrm{x}} / \mathrm{CeO}_{2}$ Catalysts for Selective Catalytic Reduction of $\mathrm{NO}_{\mathrm{x}}$ with $\mathrm{NH}_{3}$. Ind. Eng. Chem. Res. 2018;57: 12736-12741.

9. Chen X, Cao S, Weng X, Wang H, Wu Z. Effects of morphology and structure of titanate supports on the performance of ceria in selective catalytic reduction of NO. Catal. Commun.2012;26:178-182.

10. Geng Y Shan W, Liu F, Yang S. Adjustment of operation temperature window of Mn-Ce oxide catalyst for the selective catalytic reduction of $\mathrm{NO}_{x}$ with $\mathrm{NH}_{3}$. J. Hazard. Mater. 2021;405: 124223.

11. Yu L, Peng R, Chen L, Fu M, Wu J, Ye D. Ag supported on $\mathrm{CeO}_{2}$ with different morphologies for the catalytic oxidation of HCHO. Chem. Eng. J. 2018;334: 2480-2487.

12. Yao X, Chen L, Cao J, Yang F, Tan W, Dong L. Morphology and Crystal-Plane Effects of $\mathrm{CeO}_{2}$ on $\mathrm{TiO}_{2} / \mathrm{CeO}_{2}$ Catalysts during NH3-SCR Reaction. Ind. Eng. Chem. Res. 2018;57: 12407-12419.

13. Wang D, Peng Y, Yang O, Hu F, Li J, Crittenden J. $\mathrm{NH}_{3}-\mathrm{SCR}$ performance of $\mathrm{WO}_{3}$ blanketed $\mathrm{CeO}_{2}$ with different morphology: Balance of surface reducibility and acidity. Catal. Today. 2019;332: 42-48.

14. Chang H, Li J, Yuan J, Chen L, Dai Y, Arandiyan H, Xu J, Hao J. Ge, Mn-doped $\mathrm{CeO}_{2}-\mathrm{WO}_{3}$ catalysts for $\mathrm{NH}_{3}-\mathrm{SCR}$ of $\mathrm{NO}_{x}$ : Effects of $\mathrm{SO}_{2}$ and $\mathrm{H}_{2}$ regeneration. Catal. Today.2013; 201:139-144.

15. Chang H , Ma L, Yang S, Li J ,Chen L, Wang W, Hao J. Comparison of preparation methods for ceria catalyst and the effect of surface and bulk sulfates on its activity toward $\mathrm{NH}_{3}$-SCR. J. Hazard. Mater. $2013 ; 262: 782-788$. 
16. Andreoli $\mathrm{S}, \mathrm{A}$.Deorsola F, Pirone R. $\mathrm{MnO}_{x}-\mathrm{CeO}_{2}$ catalysts synthesized by solution combustion synthesis for the low-temperature $\mathrm{NH}_{3}$-SCR. Catal. Today.2015;253: 199-206.

17. Xiong Y, Tang C'Yao X'Zhang L'Li L'Wang X'Deng Y'Gao F, Dong L. Effect of metal ions doping $\left(\mathrm{M}=\mathrm{Ti}^{4+}, \mathrm{Sn}^{4+}\right)$ on the catalytic performance of $\mathrm{MnO}_{x} / \mathrm{CeO}_{2}$ catalyst for low temperature selective catalytic reduction of $\mathrm{NO}$ with $\mathrm{NH}_{3}$. APPL CATAL A-GEN. 2015;495: 206-216.

18. Liu Z'Yi Y ,Zhang S'Zhu T, Zhu J, Wang J. Selective catalytic reduction of $\mathrm{NO}_{x}$ with $\mathrm{NH}_{3}$ over Mn-Ce mixed oxide catalyst at low temperatures. Catal. Today. 2013;216: 76-81.

19. Tang C, Zhang H, Dong L. Ceria-based catalysts for low-temperature selective catalytic reduction of $\mathrm{NO}$ with $\mathrm{NH}_{3}$. Catal. Sci. Technol. 2016;6 : 1248-1264.

20. Liu C ,Shi J-W ,Gao C, Niu C. Manganese oxide-based catalysts for low-temperature selective catalytic reduction of $\mathrm{NO}_{\mathrm{x}}$ with $\mathrm{NH}_{3}$ : A review. APPL CATAL A-GEN.2016; 522:54-69.

21. Chang H'Li J'Chen X'Ma L'Yang S'Johannes, Schwank W, Hao J. Effect of Sn on $\mathrm{MnO}_{x}-\mathrm{CeO}_{2}$ catalyst for SCR of $\mathrm{NO}_{x}$ by ammonia: Enhancement of activity and remarkableresistancetoSO $\mathrm{S}_{2}$. Catal. Commun.2012;27: 54-57.

22. Wook D, Kwon, Nam K B, Hong S C. The role of ceria on the activity and $\mathrm{SO}_{2}$ resistance of catalysts for the selective catalytic reduction of $\mathrm{NO}_{\mathrm{x}}$ by $\mathrm{NH}_{3}$. Appl. Catal. B.2015;166-167:37-44.

23. Lia S, Huang B, Yua C. A $\mathrm{CeO}_{2}-\mathrm{MnO}_{\mathrm{x}}$ core-shell catalyst for low-temperature $\mathrm{NH}_{3}-\mathrm{SCR}$ of $\mathrm{NO}$. Catal. Commun.2017;98: 47-51.

24. Zhong L, Fang Q, Li X, Li Q, Zhang C, Chen G. Influence of preparation methods on the physicochemical properties and catalytic performance of Mn-Ce catalysts for lean methane combustion. APPL CATAL A-GEN.2019; 579: 151-158.

25. Wang C, Yu F, Zhu M, Tang C, Zhang K, Zhao D, Dong L, Dai B. Highly selective catalytic reduction of $\mathrm{NO}_{\mathrm{x}}$ by $\mathrm{MnO}_{\mathrm{x}}-\mathrm{CeO}_{2}-\mathrm{Al}_{2} \mathrm{O}_{3}$ catalysts prepared by self-propagating high-temperature synthesis. Res. J. Environ. Sci. 2019;75: 124-135.

26. Weiman L, Haidi L, Yunfa C. Mesoporous $\mathrm{MnO}_{\mathrm{x}}-\mathrm{CeO}_{2}$ composites for $\mathrm{NH}_{3}$-SCR: the effect of preparation methods and a third dopant. RSC Adv.2019; 9: 11912.

27. Shi Y, Yi H, Gao F, Zhao S, Xie Z, Tang X. Facile synthesis of hollow nanotube $\mathrm{MnCoO}_{\mathrm{x}}$ catalyst with superior resistance to $\mathrm{SO}_{2}$ and alkali metal poisons for $\mathrm{NH}_{3}-\mathrm{SCR}$ removal of NOx. Sep. Purif. Technol..2021;265:118517.

28. Yao X, Ma K, Zou W, He S, An J, Yang F, Dong L. Influence of preparation methods on the physicochemical properties and catalytic performance of $\mathrm{MnO}_{x}-\mathrm{CeO}_{2}$ catalysts for $\mathrm{NH}_{3}-\mathrm{SCR}$ at low temperature. Chinese J. Catal. 2017;38: 146-159.

29. Patel V K ,Sharma S. Effect of oxide supports on palladium based catalysts for NO reduction by $\mathrm{H}_{2}$-SCR. Catal. Today.2021;375: 591-600.

30. Li W, Zhang C, Li X, Tan P, Zhou A, Fang Q, Chen Q. Ho-modified Mn-Ce/ $/ \mathrm{TiO}_{2}$ for low-temperature SCR of $\mathrm{NO}_{x}$ with $\mathrm{NH}_{3}$. Chinese J. Catal.2018;39:1653-1663.

31. Chen X, Abdullah H, Kuo1 D-H. CuMnOS Nanoflowers with Different $\mathrm{Cu}^{+} / \mathrm{Cu}^{2+}$ Ratios for the $\mathrm{CO}_{2^{-}}$ to- $\mathrm{CH}_{3} \mathrm{OH}$ and the $\mathrm{CH}_{3} \mathrm{OH}$ to- $\mathrm{H}_{2}$ Redox Reactions. Sci Rep. 2017; 7: 41194.

32. Wang C, Yu F, Zhu M, Tang C, Zhang K, Zhao D, Dong L, Dai B. Highly selective catalytic reduction of $\mathrm{NO}_{\mathrm{x}}$ by $\mathrm{MnO}_{\mathrm{x}}-\mathrm{CeO}_{2}-\mathrm{Al}_{2} \mathrm{O}_{3}$ catalysts prepared by self-propagating high-temperature synthesis. Res. J. Environ. Sci.2019;75: 124-135.

33. Lin B, Liu Y, Heng L, Ni J, Lin J, Jiang L. Effect of ceria morphology on the catalytic activity of $\mathrm{Co} / \mathrm{CeO}_{2}$ catalyst for ammonia synthesis. Catal. Commun. 2017;101: 15-19.

34. Chen J'Zhao W'Wu Q'Mi J'Wang X'Ma L'Jiang L'Au C'Junhua. Effects of anaerobic $\mathrm{SO}_{2}$ treatment on nano- $\mathrm{CeO}_{2}$ of different morphologies for selective catalytic reduction of $\mathrm{NO}_{\mathrm{x}}$ with $\mathrm{NH}_{3}$. Chem. Eng. Sci.2020;382: 122910. 